\title{
Severe Abdominal Pain after Catheter Ablation for Atrial Fibrillation Caused by Propofol-Induced Pancreatitis
}

\author{
Georgy Kaspar ${ }^{1 *}$, Yessar Takruri ${ }^{2}$ and Dipak Shah ${ }^{3}$ \\ ${ }^{1}$ Department of Cardiology, Michigan State University College of Human Medicine, USA \\ ${ }^{2}$ Department of Internal Medicine, Michigan State University College of Human Medicine, USA \\ ${ }^{3}$ Department of Cardiac Electrphyiology, Michigan State University College of Human Medicine, USA
}

Submission: January 04, 2018; Published: February 20, 2018

*Corresponding author: Georgy Kaspar, Department of Cardiology, Providence-Providence Park Hospital/Michigan State University College of Human Medicine, Southfield, MI, 16001 West Nine Mile Road, Southfield, MI, USA, 48075, Tel: 248.552.9858; Fax: 248.552.9510; Email: geokaspar@hotmail.com

\begin{abstract}
The differential diagnosis of severe abdominal pain after radiofrequency catheter ablation of atrial fibrillation includes many procedurerelated complications. We present a case of severe abdominal pain post-ablation caused by propofol-induced pancreatitis diagnosed in a 39-year old male with otherwise unremarkable medical history. Given the high frequency of propofol use during catheter ablation, propofol-induced pancreatitis must be considered in the differential diagnosis of abdominal pain.
\end{abstract}

Keywords : Abdominal pain; Atrial fibrillation; Catheter ablation; Pancreatitis; Propofol

\section{Introduction}

Severe abdominal pain presenting after radiofrequency catheter ablation (RFCA) of atrial fibrillation (AF) can result from the ablation procedure itself. Commonly described causes of severe abdominal pain in this setting include referred chest pain, esophageal injury, gastroparesis, and mesenteric vascular embolization [1,2]. Considering this differential diagnosis, identification of the etiology in a timely manner is essential to prevent unanticipated morbidity, mortality and prolonged hospitalization. In addition to procedure-related complications, side-effects of anesthesia must also be considered in this setting. To illustrate this, we present a case of severe abdominal pain postRFCA caused by propofol-induced pancreatitis in a 39-year old male with otherwise unremarkable medical history.

\section{Case Presentation}

A 39-year-old male with a medical history pertinent only for paroxysmal AF presented to our hospital for RFCA. The patient underwent RFCA under monitored anesthetic care with midazolam, propofol and fentanyl. A standard ablation approach with wide antral circumferential ablation and posterior wall isolation were performed. The esophagus was delineated with an atrioesophogeal temperature probe and rose to an absolute maximum of $37.6{ }^{\circ} \mathrm{Celsius,}$ with a maximum $1{ }^{\circ} \mathrm{Celsius}$ delta difference from baseline. Hypotension was not noted during the procedure, and recovery from anesthesia was uneventful. Two hours after transfer to his hospital room, the patient started complaining of abdominal pain minimally relieved with morphine. The patient remained hemodynamically stable during this time with a blood count and metabolic panel within the normal range of values. However, this pain became severe following a meal and resulted in episodes of bilious vomiting.

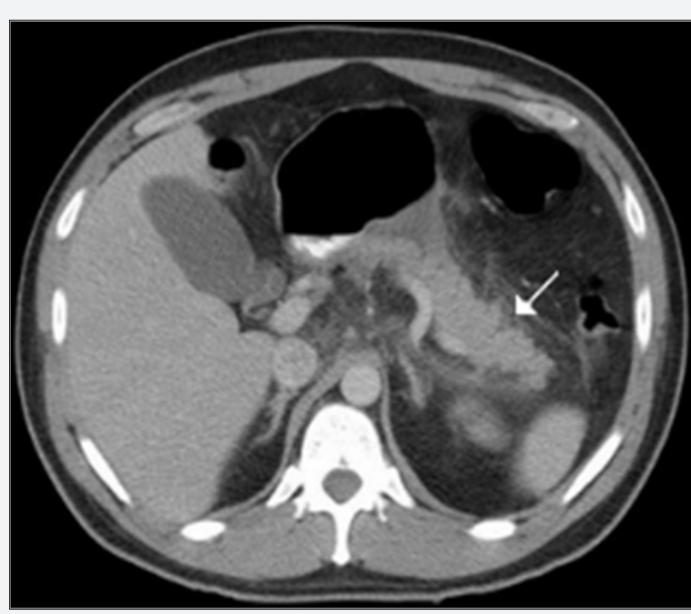

Figure 1: Infiltration of peripancreatic fat (white arrow) suggestive of acute pancreatitis. 
Additional blood tests were obtained, including a liver function panel and levels of serum amylase, lipase, calcium, lactate and triglyceride. The only laboratory abnormality was the patient's amylase and lipase, which was elevated at 359 units $\mathrm{L}^{-1}$ and 649 units $\mathrm{L}^{-1}$, respectively. A CT scan of the abdomen was performed and although it revealed no retroperitoneal bleeding, infiltration of peripancreatic fat suggestive of acute pancreatitis (Figure 1) was demonstrated.

The patient's abdominal pain was likely secondary to propofol-induced pancreatitis. This is suggested by a benign past medical and surgical history (including no alcohol use), no episodes of hypotension, and no other culprit medications or laboratory abnormalities [3]. The patient's pain improved with medical treatment including pain control and a NPO status for two days. On discharge, his serum amylase and lipase decreased to 69 units $\cdot \mathrm{L}^{-1}$ and 63 units $\cdot \mathrm{L}^{-1}$.

\section{Discussion}

Severe abdominal pain may initially be suppressed as a result of residual analgesia and sedation administered during procedures. Thus, high clinical suspicion must be maintained for any abdominal pain occurring post-RFCA. Propofol-induced pancreatitis has been reported in different clinical settings, and in some cases, may be dose-independent and severe, making prompt identification essential $[4,5]$. To our knowledge, this is the first reported case of propofol-induced pancreatitis following cardiac ablation, and it illustrates severe abdominal pain outside of the realm of traditionally reported procedure-related complications.

\section{Conclusion}

Although rarely observed, given the high frequency of propofol use, propofol-induced pancreatitis must be considered in the differential diagnosis of abdominal pain post-RFCA of AF with the appropriate clinical setting. Early identification is essential to stratify patient management and to avoid prolonged hospitalization.

\section{References}

1. Baman TS, Jongnarangsin K, Chugh A, Suwanagool A, Guiot A, et al. (2011) Prevalence and predictors of complications of radiofrequency catheter ablation for atrial fibrillation. J Cardiovasc Electrophysiol 22(6): 626-631.

2. Knopp H, Halm U, Lamberts R, Knigge I, Zachäus M, et al. (2014) Incidental and ablation-induced findings during upper gastrointestinal endoscopy in patients after ablation of atrial fibrillation: A retrospective study of 425 patients. Heart Rhythm 11(4): 574-578.

3. Balani AR, Grendell JH (2008) Drug-induced pancreatitis: incidence, management and prevention. Drug Safety 31(10): 823-837.

4. Jawid Q Presti ME, Neuschwander-Tetri BA, Burton FR (2002) Acute pancreatitis after single-dose exposure to propofol: a case report and review of literature. Dig Dis Sci 47(3): 614-618.

5. Muniraj T, Aslanian HR (2012) Hypertriglyceridemia independent propofol-induced pancreatitis. JOP 13(4): 451-453.

Your next submission with Juniper Publishers will reach you the below assets

- Quality Editorial service

- Swift Peer Review

- Reprints availability

- E-prints Service

- Manuscript Podcast for convenient understanding

- Global attainment for your research

- Manuscript accessibility in different formats

( Pdf, E-pub, Full Text, Audio)

- Unceasing customer service

Track the below URL for one-step submission https://juniperpublishers.com/online-submission.php 